\title{
Ethnobotanical Study of Munshiganj in Shyamnagar Upazilla, Satkhira, Bangladesh
}

\author{
${ }^{1}$ Tama Ray and ${ }^{2}$ Kingson Mondal \\ ${ }^{1}$ Tama Ray, Co- Founder, Conservation Club, Khulna, Bangladesh. \\ ${ }^{2}$ Kingson Mondal, Founder, Conservation Club, Khulna, Bangladesh.
}

Received date: 10 January 2018, Accepted date: 28 March 2018, Online date: 4 April 2018

\author{
Address For Correspondence: \\ Tama Ray, Khulna University, Forestry and Wood Technology, Khulna- 9208, Khulna , Bangladesh \\ E-mail: tamaray123@gmail.com
}

Copyright () 2018 by authors and American-Eurasian Network for Scientific Information. This work is licensed under the Creative Commons Attribution International License (CC BY). http://creativecommons.org/licenses/by/4.0/

\section{(C) (i) Open Access}

\begin{abstract}
Background: Bangladesh is very rich in floral diversification having almost 5000 species; but the thing is that the existence of floral community is now at stake due to diminishing knowledge of the local people about the uses and importance of plant species as the societies are going through a changing lifestyle; as a result, they are showing harsh behavior to the plant population to fulfill their satisfaction. Objective: In our study, we tried to document the species' availability, composition and diversity of the study area as well as the ethnobotanical knowledge of the people residing there about the uses of plant species in order to transfer that knowledge from generation to generation for helping in the long-term plant species conservation. Results: 44 species under 27 families were cited by the interviewee and 25 species out of 44 have food value which is the highest use value of all categories (Food, Construction, Medicine, Fuelwood and Other). To understand the diversity and significance of the species in that area, 'Use Value' and 'Fidelity Level' were calculated where the 'Use Value' ranges from 0.01 to 0.5 and 'Fidelity Level' is from 50\% to 100\%.Conclusion: Diversity, composition and significance of plant species of Munshiganj area have been identified through the analysis of empirical methods 'Use value' and 'Fidelity level' as well as documentation of ethnobotanical knowledge of the local people about the versatile uses of plant species has been prepared. The result will provide us a scenario of the interaction of the local people with plant species and the traditional ethnobotanical knowledge will help to retain their surrounding green environment.
\end{abstract}

\section{KEY WORDS}

Munshiganj, Ethnobotanical investigation, Use value category, Use value, Fidelity level.

\section{INTRODUCTION}

Plants are the base of life on this beautiful earth where plants support human being with life- supporting oxygen and livelihood [20] as well as they are the source of food, forage, medicines, house construction, firewood, sleeping mats and shade along with ritual and commercial elements and so on [8]. In this way, plants and people are sharing a close natural relationship among themselves [21] called 'Ethnobotany' [6]. This traditional ethnobotanical knowledge is forming an interaction with the practices of the people that helps to shape the ecosystem and affects the management of our surrounding plant populations [7].

Shyamnagarupazila is a sub district of Satkhira district $\left(22^{\circ} 19.8^{\prime} \mathrm{N}, 89^{\circ} 6.2^{\prime} \mathrm{E}\right)$ [1] [3] which is well recognized for its vulnerability to natural disasters and considered as the most vulnerable upazilla of the cost [3]. Munshiganj is one of the unions among 11 unions of Shyamnagarupazilla which is situated by the side of the Sundarbans and its southern part is covered by the Sundarbans mangrove forest [4]. The livelihoods of coastal people are highly dependent on natural resources [9]. Different disasters like cyclone, monsoon storm, riverbank erosion, salinity intrusion, expansion of settlement, industry and infrastructure as well as degradation of the ecosystem are the common affairs in that region. [3]. So, societies are going through different transitions of lifestyle, such as growth of population, their crowding and migration as well as habitat degradation, land encroachment, biological incursions, climate change, different epidemiological hazards, imported technologies, 
schooling, mass media, religious conversion, cultural imperialism, changing perception, as well as utilization, management and extraction of natural resources and so on. As a result, local communities are trying to adopt with shifting life conditions and a drastic change is occurring between human and floral community [35]. That is why, ethnobotanical knowledge conservation is very important [32] [2] to identify the plants perceived by the people through their mode of usage [23].

As traditional ethnobotanical knowledge is a fast-growing field of science and people with the varying academic environment are showing interests in this research [12], several studies of [5] [16] [17] [19] [22] [24] [25] [26] [28] [29] [30] [31] [33] [34] and so on have been found in which they tried to document the ethnic medicinal values of plant species of Bangladesh in order to preserve and transmit ethnobotanical knowledge. But in most cases, ethnomedicinal documentation has got priority though other uses of plant species are equally important to perceive the plants in our society. That's why, we have tried to make a documentation of all indigenous uses of plant species for the conservation of both cultural and biological diversities of plants [8].

Methodology:

Our study was carried out in Munshiganj union $\left(22^{\circ} 14^{\prime}-22^{\circ} 17^{\prime}\right.$ N- $89^{\circ} 04^{\prime}-89^{\circ} 12^{\prime}$ of ShyamnagarUpazilla under Sathkhira division. The area is very close to Sundarbans and its southern part is covered by the forest[3].

Three villages named 'PurbaKalinagar', 'CetreKalinagar' and Dakshin Kadamtola of Munshiganj union were selected for ethnobotanical investigation. A semi-structured questionnaire was prepared and the data was collected through questionnaire survey and informal interview. Total 90 households were chosen randomly as the sample (30 from each village). The voucher specimen was collected for proper identification.

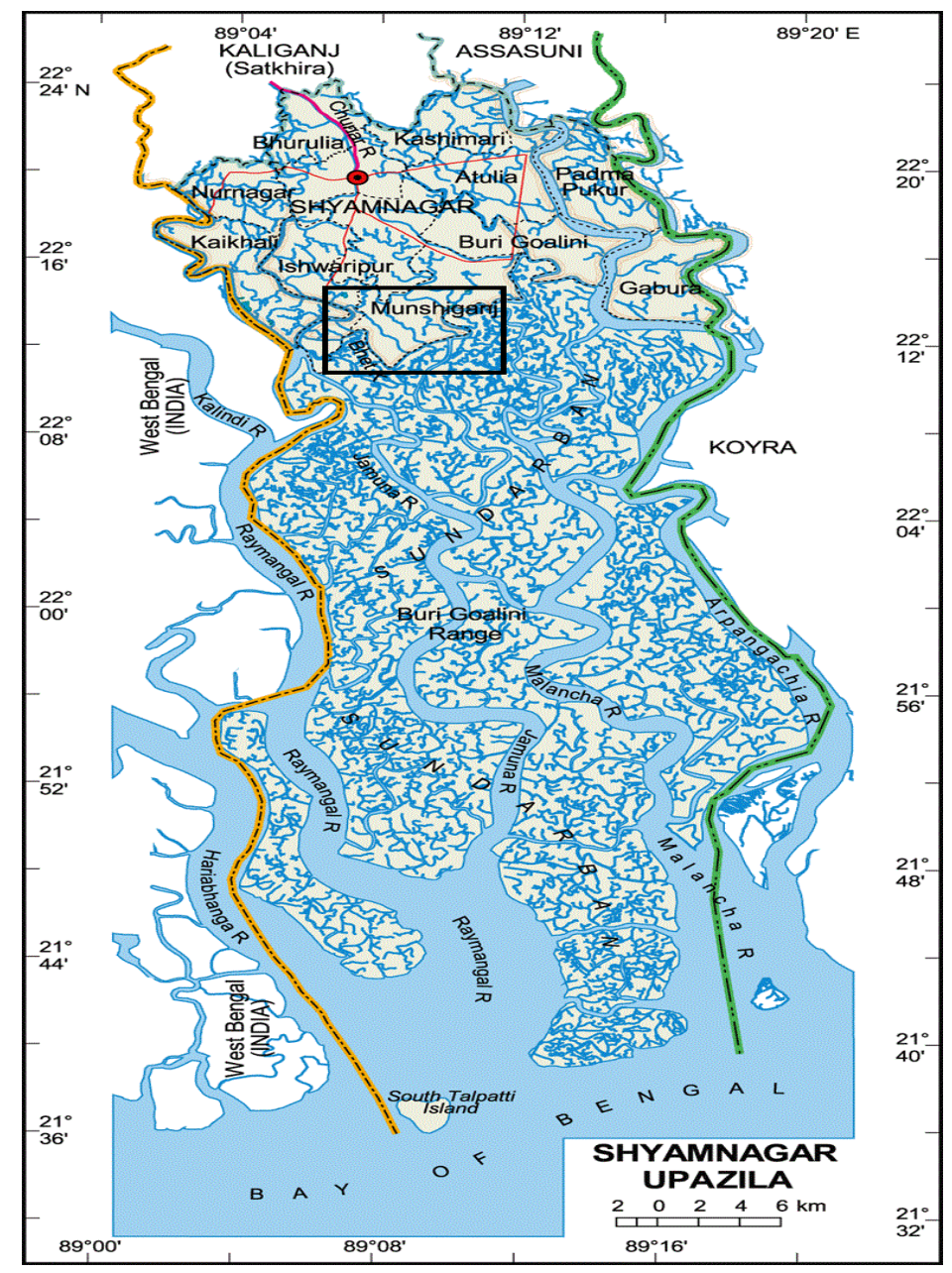

Fig. 1: Location of Munshiganj, Shyamnagar, Satkhira (Source: http://www.thebangladesh.net/upazilas-ofsatkhira/shyamnagar-upazila.html

After data collection, data were categorized according to use category (food, construction, medicine, fuelwood and other). Use value $\left(\mathrm{UV}_{\mathrm{s}}\right)$ and Fidelity level (FL) were calculated to show the diversity and significance of the use of species. Higher Fidelity Level indicates extensive use of plant species by the local people [14]. 
$\mathrm{UV}_{\mathrm{s}}=\sum_{\mathrm{i}} \mathrm{UV}_{\mathrm{is}} / \mathrm{n}_{\mathrm{s}}$

$\mathrm{UV}_{\mathrm{is}}$ is the number of use reports mentioned by the informants for that particular plant species and $\mathrm{n}_{\mathrm{s}}$ is the total number of informants participated in our study.

$\mathrm{FL}=\mathrm{I}_{\mathrm{p}} / \mathrm{I}_{\mathrm{u}} \times 100$

$I_{P}$ is the number of informants stating the use of a species for a particular use and $I_{u}$ is the number of informants stating the use of that plant for any sort of use. Higher FL value indicates more frequent use of a given species for the particular ailment [14] [10] [32].

\section{RESULTS AND DISCUSSION}

Cited Species:

Total 90 people were interviewed of that area and 44 species of 27 families were mentioned by them. Table 1 and Figure 1 represents name and distribution of the species according to their family.

Table 1: Name of species according to their family

\begin{tabular}{|c|c|c|c|}
\hline Family & Name of Species & Family & Name of Species \\
\hline Acanthaceae & Adhatodavasica & \multirow[b]{2}{*}{ Malvaceae } & Bombax ceiba \\
\hline Anacardiaceae & Mangifera Indica & & Gossypium arboretum \\
\hline Apiaceae & Centellaasiatica & \multirow[b]{2}{*}{ Meliaceae } & Azadiractaindica \\
\hline Apocynaceae & Calotropis gigantean & & Swieteniamahagony \\
\hline \multirow[t]{4}{*}{ Arecaceae } & Phoenix sylvestris & Moraceae & Artocarphusheterophyllus \\
\hline & Borassusflaballifer & Moringaceae & Moringa oleifera \\
\hline & NypaFruticans & Musaceae & Musa spp. \\
\hline & Phoenix paludosa & \multirow[b]{4}{*}{ Myrtaceae } & Psidium guajava \\
\hline Caricaceae & Carica papaya & & Syzygiumcumini \\
\hline Combretaceae & Terminalia catappa & & Syzygiumsamarangense \\
\hline Ebenaceae & Diospyros peregrine & & Eucalyptus obliqua \\
\hline Elaeocarpaceae & Elaeocarpus robustus & Palmae & Cocos nucifera \\
\hline Euphorbiaceae & Excoecariaagallocha & Phyllanthaceae & Phyllanthus acidus \\
\hline \multirow[t]{5}{*}{ Fabaceae } & Tamarindus indicus & Poaceae & Bambusa spp. \\
\hline & Albizialebbeck & Rhamnaceae & Zizyphusmauritiana \\
\hline & Acacia auriculiformis & \multirow[b]{4}{*}{ Rutaceae } & Aegle marmelos \\
\hline & Vachellianilotica & & Feronia limonia \\
\hline & Pithecellobium dulce & & Citrus aurantifolia \\
\hline Lamiaceae & Ocimumtenuiflorum & & Citrus grandis \\
\hline \multirow[t]{3}{*}{ Lythraceae } & Lawsoniainermis & Sapindaceae & Lichichinensis \\
\hline & Punicagranatum & Sapotaceae & Manilkarazapota \\
\hline & Sonneratiaapetala & Sterculiaceae & Heritierafomes \\
\hline
\end{tabular}

Among 27 families, Fabaceae has the highest number of species (5). Areceae and Myrtaceae represents second highest number of species, that is 4 .

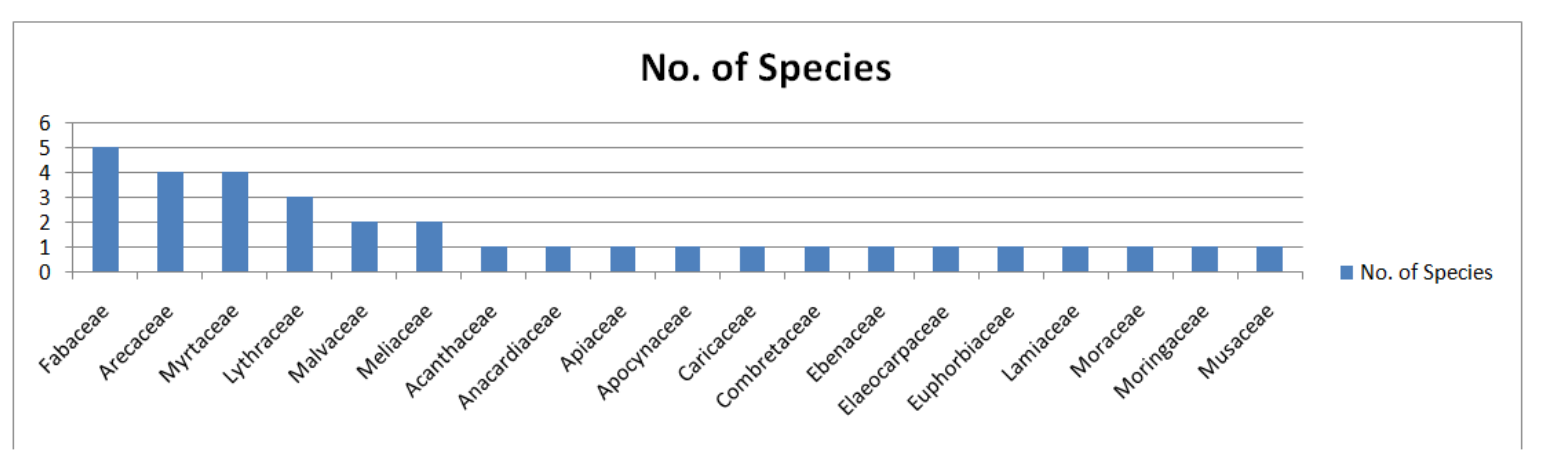

Fig. 2: Distribution of species according to their familyUses of plant species

Table 2: Uses of species under major use category

\begin{tabular}{|c|c|c|c|c|c|c|}
\hline & & \multicolumn{5}{|c|}{ Plant Use } \\
\hline Local Name & Scientific Name & Food & Construction & Medicine & Fuel Wood & Other \\
\hline Narikel & Cocos nucifera & $\mathrm{X}$ & & & $\mathrm{x}$ & $\mathrm{x}$ \\
\hline Kola & Musa spp. & $\mathrm{x}$ & & & & \\
\hline Khejur & Phoenix sylvestris & $\mathrm{x}$ & & & & $\mathrm{x}$ \\
\hline Aam & Mangifera Indica & $\mathrm{x}$ & & & & \\
\hline Katbadam & Terminalia catappa & $\mathrm{x}$ & & & & \\
\hline Mehedi & Lawsoniainermis & & & & & $\mathrm{x}$ \\
\hline
\end{tabular}




\begin{tabular}{|c|c|c|c|c|c|c|}
\hline Peyera & Psidium guajava & $\mathrm{x}$ & & & & \\
\hline Sundri & Heritierafomes & & $\mathrm{x}$ & & & \\
\hline Bel & Aegle marmelos & $\mathrm{x}$ & & & & $\mathrm{x}$ \\
\hline Tetul & Tamarindus indicus & $\mathrm{x}$ & $\mathrm{x}$ & & & \\
\hline Shirish & Albizialebbeck & & $\mathrm{x}$ & & & \\
\hline Neem & Azadiractaindica & & & $\mathrm{x}$ & & \\
\hline Jam & Syzygiumcumini & $\mathrm{x}$ & & & & \\
\hline Sobeda & Manilkarazapota & $\mathrm{x}$ & & & & \\
\hline Kul & Zizyphusmauritiana & $\mathrm{x}$ & & & & \\
\hline Jarmul & Syzygiumsamarangense & $\mathrm{x}$ & & & & \\
\hline Mehogany & Swieteniamahagony & & $\mathrm{x}$ & & & \\
\hline Kadbel & Feronia limonia & $\mathrm{x}$ & & & & \\
\hline Nol & Phyllanthus acidus & & & & & \\
\hline Eucalyptus & Eucalyptus obliqua & & $\mathrm{x}$ & & $\mathrm{x}$ & \\
\hline Taal & Borassusflaballifer & $\mathrm{x}$ & & & & \\
\hline Gab & Diospyros peregrina & $\mathrm{x}$ & & & & $\mathrm{x}$ \\
\hline Pepe & Carica papaya & $\mathrm{x}$ & & & & \\
\hline Akashmoni & Acacia auriculiformis & & & & $\mathrm{x}$ & \\
\hline Kagojilebu & Citrus aurantifolia & $\mathrm{x}$ & & $\mathrm{x}$ & & \\
\hline BatabiLebu & Citrus grandis & $\mathrm{x}$ & & & & \\
\hline Dalim & Punicagranatum & $\mathrm{x}$ & & $\mathrm{x}$ & & \\
\hline Bash & Bambusa spp. & & $\mathrm{x}$ & & & \\
\hline Kanthal & Artocarphusheterophyllus & $\mathrm{x}$ & & & & \\
\hline Tulsi & Ocimumtenuiflorum & & & $\mathrm{x}$ & & $\mathrm{x}$ \\
\hline Gewa & Excoecariaagallocha & & & $\mathrm{x}$ & & \\
\hline Golpata & Nypafruticans & & $\mathrm{x}$ & & & $\mathrm{x}$ \\
\hline Lichu & Lichichinensis & $\mathrm{x}$ & & & & \\
\hline Jolpai & Elaeocarpus robustus & $\mathrm{x}$ & & & & \\
\hline Sojina & Moringa oleifera & $\mathrm{x}$ & & & & \\
\hline Thankuni & Centellaasiatica & & & $\mathrm{x}$ & & \\
\hline Keora & Sonneratiaapetala & $\mathrm{x}$ & & & & \\
\hline Shimul Tula & Bombax ceiba & & & & & $\mathrm{x}$ \\
\hline Karpas Tula & Gossypium arboretum & & & & & $\mathrm{x}$ \\
\hline Babla & Vachellianilotica & & & & $\mathrm{x}$ & \\
\hline Khoyebabla & Pithecellobium dulce & $\mathrm{x}$ & & & & \\
\hline Akando & Calotropis gigantean & & & $\mathrm{x}$ & & \\
\hline Hetal & Phoenix paludosa & & & & & $\mathrm{x}$ \\
\hline Basok & Adhatodavasica & & & $\mathrm{x}$ & & \\
\hline
\end{tabular}

According to the information, the highest number of species were categorized under 'Food' use value. 25 species out of 44, has food value whereasonle 4 species were found which has fuelwood value.

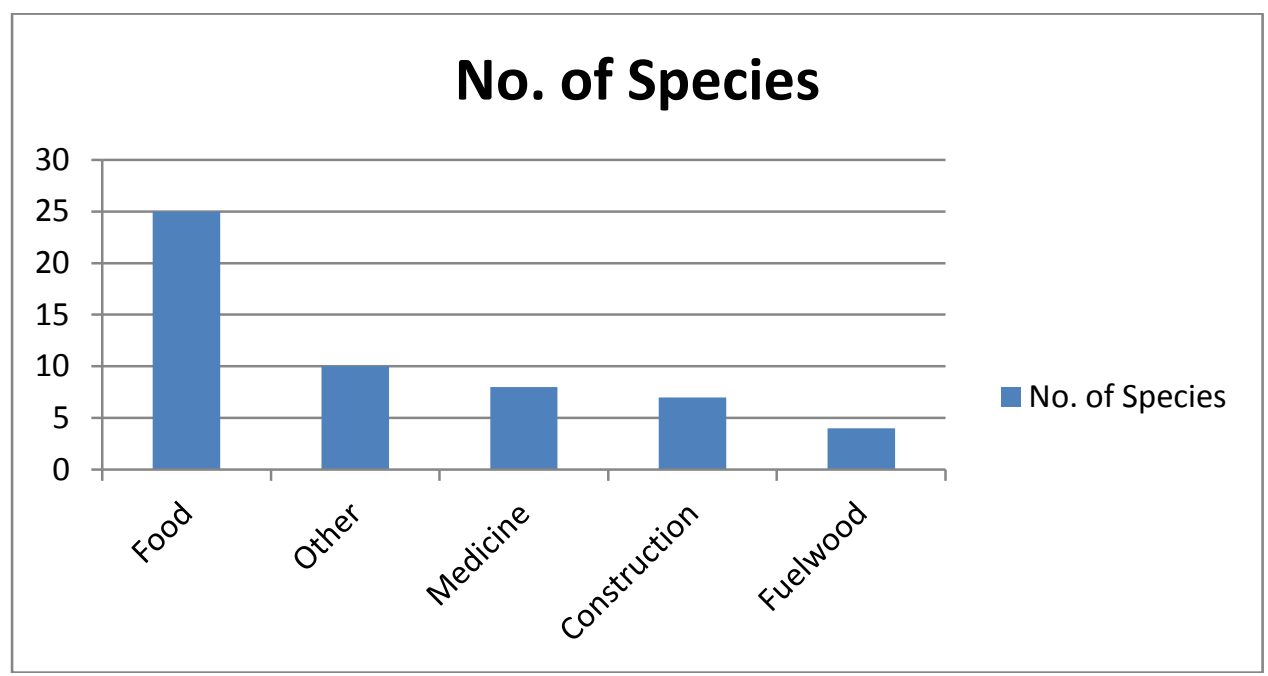

Fig. 3: No. of species under major use category Analysis of Use Value and Fidelity Level 
Table 3: Use value and Fidelity level of reported species

\begin{tabular}{|c|c|c|c|c|c|}
\hline Scientific Name & $\begin{array}{l}\text { No. of informants who reported use of } \\
\text { species }\end{array}$ & $\begin{array}{l}\text { No. of uses by } \\
\text { species }\end{array}$ & $\begin{array}{l}\text { Primary } \\
\text { use }\end{array}$ & $\begin{array}{l}\text { Use } \\
\text { Value } \\
\end{array}$ & FL $\%$ \\
\hline Cocos nucifera & 45 & 3 & Food & 0.52 & 93.33 \\
\hline Musa spp. & 6 & 1 & Food & 0.06 & 100 \\
\hline Phoenix sylvestris & 16 & 2 & Food & 0.18 & 56.25 \\
\hline Mangiferaindica & 18 & 1 & Food & 0.2 & 100 \\
\hline Terminalia catappa & 4 & 1 & Food & 0.04 & 100 \\
\hline Lawsoniainermis & 2 & 1 & Other & 0.02 & 100 \\
\hline Psidium guajava & 23 & 1 & Food & 0.26 & 100 \\
\hline Heritierafomes & 4 & 1 & $\begin{array}{l}\text { Constructi } \\
\text { on }\end{array}$ & 0.03 & 75 \\
\hline Aegle marmelos & 2 & 2 & $\begin{array}{l}\text { Food } \\
\text { Other }\end{array}$ & 0.02 & 50 \\
\hline Tamarindus indicus & 10 & 2 & Food & 0.16 & 100 \\
\hline Albizialebbeck & 16 & 1 & $\begin{array}{l}\text { Constructi } \\
\text { on }\end{array}$ & 0.18 & 100 \\
\hline Azadiractaindica & 24 & 1 & Medicine & 0.24 & 91.67 \\
\hline Syzygiumcumini & 7 & 1 & Food & 0.08 & 100 \\
\hline Manilkarazapota & 24 & 1 & Food & 0.27 & 100 \\
\hline Zizyphusmauritiana & 22 & 1 & Food & 0.24 & 100 \\
\hline $\begin{array}{l}\text { Syzygiumsamarang } \\
\text { ense }\end{array}$ & 8 & 1 & Food & 0.09 & 100 \\
\hline Swieteniamahagony & 10 & 1 & $\begin{array}{l}\text { Constructi } \\
\text { on }\end{array}$ & 0.11 & 100 \\
\hline Feronia limonia & 5 & 1 & Food & 0.06 & 100 \\
\hline Phyllanthus acidus & 5 & 1 & Food & 0.06 & 100 \\
\hline Eucalyptus obliqua & 4 & 2 & Fuelwood & 0.04 & 75 \\
\hline Borassusflaballifer & 11 & 1 & Food & 0.12 & 100 \\
\hline $\begin{array}{l}\text { Diospyros } \\
\text { peregrina }\end{array}$ & 4 & 2 & Other & 0.04 & 75 \\
\hline Carica papaya & 2 & 1 & Food & 0.02 & 100 \\
\hline $\begin{array}{l}\text { Acacia } \\
\text { auriculiformis }\end{array}$ & 10 & 1 & Fuelwood & 0.11 & 100 \\
\hline Citrus aurantifolia & 8 & 2 & Food & 0.09 & 75 \\
\hline Citrus grandis & 4 & 1 & Food & 0.04 & 100 \\
\hline Punicagranatum & 6 & 2 & Food & 0.07 & 83.33 \\
\hline Bambusa spp. & 1 & 1 & $\begin{array}{l}\text { Constructi } \\
\text { on }\end{array}$ & 0.01 & 100 \\
\hline $\begin{array}{l}\text { Artocarphusheterop } \\
\text { hyllus }\end{array}$ & 1 & 1 & Food & 0.01 & 100 \\
\hline Ocimumtenuiflorum & 4 & 2 & Other & 0.04 & 75 \\
\hline $\begin{array}{l}\text { Excoecariaagalloch } \\
a\end{array}$ & 5 & 1 & Medicine & 0.03 & 60 \\
\hline Nypafruticans & 2 & 1 & Other & 0.02 & 100 \\
\hline Lichichinensis & 1 & 1 & Food & 0.01 & 100 \\
\hline $\begin{array}{l}\text { Elaeocarpus } \\
\text { robustus }\end{array}$ & 1 & 1 & Food & 0.01 & 100 \\
\hline Moringa oleifera & 1 & 1 & Food & 0.01 & 100 \\
\hline Centellaasiatica & 1 & 1 & Medicine & 0.01 & 100 \\
\hline Sonneratiaapetala & 3 & 1 & Food & 0.03 & 100 \\
\hline Bombax ceiba & 4 & 2 & Other & 0.04 & 50 \\
\hline
\end{tabular}




\begin{tabular}{|l|l|l|l|l|l|}
\hline $\begin{array}{l}\text { Gossypium } \\
\text { arboretum }\end{array}$ & 1 & 1 & Other & 0.01 & 100 \\
\hline Vachellianilotica & 5 & 1 & Fuelwood & 0.03 & 60 \\
\hline $\begin{array}{l}\text { Pithecellobium } \\
\text { dulce }\end{array}$ & 1 & 1 & Food & 0.01 & 100 \\
\hline $\begin{array}{l}\text { Calotropis } \\
\text { gigantean }\end{array}$ & 2 & 1 & Medicine & 0.02 & 100 \\
\hline Phoenix paludosa & 1 & 1 & Other & 0.01 & 100 \\
\hline Adhatodavasica & 1 & 1 & Medicine & 0.01 & 100 \\
\hline
\end{tabular}

Uses of species under 'Other Use Category'

Under 'Other' use category, different types of uses of each species have been documented according to the information provided by the interviewees.

Table 4:Uses of species under 'Other Use Category':

\begin{tabular}{|l|l|}
\hline Scientific Name & Other Use Category \\
\hline Cocos nucifera & To make brush to clean house \\
\hline Lawsoniainermis & Making mats \\
\hline Aegle marmelos & Coloring hands and hair \\
\hline Diospyros peregrine & Worshipping to God \\
\hline Ocimumtenuiflorum & $\begin{array}{l}\text { Coloring and making a layer on the thread to make the thread } \\
\text { strong }\end{array}$ \\
\hline Nypafruticans & Worshipping to God \\
\hline Bombax ceiba & Thaching Roof \\
\hline Gossypium arboretum & Making pillow and blanket and worshipping to God \\
\hline Phoenix paludosa & Worshipping to God \\
\hline
\end{tabular}

According to the investigation, 25 species out of 44 have food value that is the highest among all the categories. They have also mentioned five medicinal species named Azadiractaindica, Excoecariaagallocha, Centellaasiatica, Calotropis gigantean, Calotropis gigantean and Adhatodavasicawhich they are using in their daily life. But some of the other species mentioned by them have the medicinal value which is previously documented. Stem juice of Phoenix sylvestris is used for the treatment of paralysis caused by high blood pressure. Traditionally brain disorder (incoherent talk, hot temper) is treated by seed oil of Cocos nucifera. Pills made from the seeds of Syzygiumcumini is taken by the diabetes patients. Fruits of Aegle marmelos is taken when anyone suffers from Chronic dysentery and indigestion. Moringa oleifera is usually used as a vegetable (food), but the juice from the ripe leaves is used for the treatment of cancer [18] [15].

Contribution of this subject to knowledge:

Ethnobotanical knowledge varies within and outside of culture as well as it differs with regions. So, knowledge of uses of plant species is quite different from one society to another; from one country to others. On the other hand, the life of people is facing drastic changes and everyone is running for their desire life. As a result, they are leaving their knowledge about the uses of plants and trying to remove the unnecessary things from their lives [35] Ethnobotany is that kind of subject where information about various uses of plant species of different societies can be recorded through investigation. In this way, knowledge of one society can be passed from generation to generation as well as to other societies. This exchanging behavior of ethnobotanical investigation will help to enrich the knowledge of people. They can engage themselves in further research work to go to the depth of information about uses of plants and all of these efforts will help to conserve our nature.

\section{Conclusion and Recommendation:}

The extinction of knowledge of different uses of plants with the dying of old and knowledgeable people, the lack of transmission of ethnobotanical knowledge from one generation to the other [11] [13] as well as the scarcity of information of multiple uses of plant species [27] are the reasons of peoples' rude mentality towards trees. So, ethnobotanical knowledge conservation is considered as very important element in the context of reducing the destruction of floral community [32] [2].

So, to have the great scenario of diverse plant species and their uses, we have used 'Use value' and 'Fidelity level' as the targeted quantitative methods for the analysis of gathered ethnobotanical data. These methods have proved their significance in having a new understanding of people's interactions with their environment. To get more precise insight we have divided the uses of plant species into five categories (food, construction, medicine, fuelwood and other) and with the help of the quantitative methods, we have easily got the knowledge about the dependency of people on varieties of plant species based on the use category. Most interesting data that have been revealed through the investigation is that people are mostly preserving the knowledge of food and giving 
priority to conserve the plant species having food value first though other uses are equally important. That is why, it is our effort, to sum up the knowledge of uses of plants species of Munshiganj area to transfer the knowledge to younger ones so that they conserve the plant populations knowing the importance. And in this way, it is a small contribution to the ethnobotanical knowledge conservation of Bangladesh.

People of that area are interested in keeping traditional way of use of trees and the important thing is that during the investigation, some young people were also found who proved their knowledge about the traditional and cultural uses of plants. But it is not possible to say whether young people are getting complete knowledge of the ethnobotanical use of plants from the older generation or not. So, further research is necessary on ethnobotanical knowledge transfer. In addition, the region suffering from poverty, economic strife, hunger and natural hazards, it is difficult to retain the useful species getting culturally. So, how these hazards are affecting the conservation of plant species through traditional ethnobotanical knowledge is a burning question.

\section{ACKNOWLEDGEMENT}

We acknowledge all the people who have helped us through providing information about the ethnobotanical uses of different plant species.

\section{REFERENCES}

[1] Adibul Islam, M., M. Shariful Islam, M. Abdul Wahab, 2016. Impacts of Climate Change on Shrimp Farming in the South-West Coastal Region of Bangladesh. RESEARCH in AGRICULTURE LIVESTOCK AND FISHERIES., 3(1): 227-239.

[2] Ahmad, M., S. Sultana, S. Fazl-i-Hadi, T. Ben Hadda,S. Rashid, M. Zafar, M. Ajab Khan, M.P. Zada Khan, G. Yaseen, 2014. An Ethnobotanical Study of Medicinal Plants in High Mountainous Region of Chail Valley (District Swat-Pakistan). JOURNAL OF ETHNOBIOLOGY AND ETHNOMEDICINE., 10(1): 36.

[3] Akbar, M.S., M.H. Sarker, M.A. Sattar, G.M. Sarwar, S.M.M. Rahman, M.M. Rahman, Z.U. Khan, 2017. Integrated Use of Remote Sensing, GIS and GPS Technology for Monitoring the Environmental Problem of Shyamnagar. THE INTERNATIONAL ARCHIVES OF PHOTOGRAMMETRY., 42: 357.

[4] Al-Amin Hoque, M., U. Saika, B. Chandra Sarder, K. kumarbiswas, 2013. Environmental and Socioeconomic Impacts of Salinity Intrusion in the Coastal Area: A Case Study on Munshigong Union, Shymnagor, Satkhira. JAHANGIRNAGAR UNIVERSITY ENVIRONMENTAL BULLETIN., 2: 41-49.

[5] Arif Hasan, S., M. Mahtab Uddin, K. Nazib-ul Huda, A. Das, N. Tabassum, M. Rafat Hossain, M. Jumrut Mahal, M. Rahmatullah, 2014. Ethnomedicinal Plants of Two Village Folk Medicinal Practitioners in Rajshahi District, Bangladesh: Comparison of Their Folk Medicinal Uses with Ayurvedic Uses. AMERICAN-EURASIAN JOURNAL OF SUSTAINABLE AGRICULTURE., 8(1): 10-19.

[6] Ashagre Eshete, M., E. Kelbessa, G. Dalle, 2016. Ethnobotanical Study of Medicinal Plants in GujiAgropastoralists, Blue Hora District of Borana Zone, Oromia region, Ethiopia. JOURNAL OF MEDICINAL PLANT STUDIES., 4(2): 170-84.

[7] Baldauf, C., F.A.M. Dos Santos, 2013. Ethnobotany, Traditional Knowledge, and Diachronic Changes in Non-Timber Forest Products Management: a case study of HimatanthusDrasticus (Apocynaceae) in the Brazilian Savanna. ECONOMIC BOTANY., 67(2): 110-120.

[8] Gemedo-Dalle, T.L.,B. Maass, J. Isselstein, 2005. Plant Biodiversity and Ethnobotany of Borana Pastoralists in Southern Oromia, Ethiopia. ECONOMIC BOTANY., 59(1): 43-65.

[9] Ghulam Hussain, S., 2014. An Introduction to the Coasts and the Sundarbans. Gain. P., (ed), 2013. Shores of Tears. SOCIETY FOR ENVIRONMENT AND HUMAN DEVELOPMENT., pp: 01-19.

[10] Hoffman, B., T. Gallaher, 2007. Importance Indices in Ethnobotany. ETHNOBOTANICAL RESEARCH AND APPLICATION., 5: 201-218.

[11]Idu. M., 2009. Ethnobotany Today-who Are the Players? TROPICAL JOURNAL OF PHARMACEUTICAL RESEARCH., 8(4): 295-296.

[12] Ashok, K., P., Chandra, Y. Tripathi, 2017. Ethnobotany and its Relevance in Contemporary Research. JOURNAL OF MEDICINAL PLANTS., 5(3): 123-129.

[13] Kargıŏ̆lu, M., S. Cenkci, A. Serteser, N. Evliyaoğlu, M. Konuk, M. SamilKök, Y. Bağc1, 2008. An Ethnobotanical Survey of Inner-West Anatolia, Turkey. HUMAN ECOLOGY., 36(5): 763-777.

[14] Khan, I.M.,N. AbdElsalam, H. Fouad, A. Tariq, R. Ullah, M. Adnan, 2014. Application of Ethnobotanical Indices on the Use of Traditional Medicines against Common Diseases. EVIDENCE- BASED COMPLEMENTARY AND ALTERNATIVE MEDICINE.

[15] Mahabub Nawaz, A.H.M., M. Hossain, M. Karim., M. Khan, R. Jahan, M. Rahmatullah, 2009. An Ethnobotanical Survey of Rajshahi District in Rajshahi Division, Bangladesh. AMERICAN-EURASIAN JOURNAL OF SUSTAINABLE AGRICULTURE., 3(2): 143-150. 
[16] Mahbubur Rahman, A.H.M., 2014. Ethno-medicinal Practices for the Treatment of Asthma, Diuretic, Jaundice, Piles, Rheumatism and Vomiting at the Village Abdullahpur under Akkelpur Upazilla of Joypurhat District, Bangladesh. INTERNATIONAL JOURNAL OF ENGINEERING AND APPLIED SCIENCES., 1(2): 4-8.

[17] Mahnoor, N., I. Farha Moonmoon, T. Saha, K. Mahamud, S. Biswas, E. Islam, M. Rahmatullah, 2015. Medicinal Plants of a Folk Herbalist in Tangail District, Bangladesh. AMERICAN-EURASIAN JOURNAL OF SUSTAINABLE AGRICULTURE., 9(4): 74- 82.

[18] Nahar, S., M. Rahmatullah, 2016. Plants, Animals, Birds, Insects, Minerals-all Are Medicines to a Folk Medicinal Practitioner in Nilphamari District, Bangladesh. WORLD JOURNAL OF PHARMACY AND PHARMACEUTICAL SCIENCES., 5(4): 2422-2439.

[19] Nahar, S., B. Ferdous, T. Dutta, U. Faria Rashid, T. Nahian Tasnim, S. Akter, S. Moin Mou, M. Rahmatullah, 2013. Influences in Folk Medicine- A Case Study of Folk Medicinal Practitioner of Jhalokathi in Barisal District, Bangladesh. AMERICAN-EURASIAN JOURNAL OF SUSTAINABLE AGRICULTURE., 7(4): 295- 305.

[20] Narayan Pradhan, R., O. Rautaraya, P. Behera, S. Kumar Panda, 2014. Diversity, Medicinal Uses and Conservation Status of Medicinal Plants at Mandaragiri, Angul Forest Division, Odisha, India. NATURAL RESOURCES AND CONSERVATION., 2(3): 43-50.

[21] Partha, P., 2014. Ethnobotany of the Laleng (Patra) Community in Bangladesh. JOURNAL OF PHARMACOGNOSY AND PHYTOCHEMISTRY., 2(6).

[22] Partha, P., A.B.M. Enayet Hossain, 2007. Ethnobotanical Investigation into the Mandi Ethnic Community in Bangladesh. BANGLADESH JOURNAL OF PLANT TAXONOMY., 14(2): 129-145.

[23] Rahman, A.H.M.M., E.Z.M.F. Kabir, N.S. Sima, R.S. Sultana, M. Nasiruddin, A.T.M.N. Zaman, 2010. Study of an Ethnobotany at the Village Dohanagar, Naogaon. JOURNAL OF APPLIED SCHIENCES RESEARCH., 6(9), 1466-1473.

[24] Rahmatullah, M., Z. Khatun, A. Hasan, W. Parvin, M. Moniruzzaman, A. Khatun, M. Jumrut Mahal, M.S. Alam Bhuiyan, S. Moin Mou, R. Jahan., 2012. Survey and Scientific Evaluation of Medicinal Plants used by the Pahan and Teli Tribal Communities of Natore district, Bangladesh. AFRICAN JOURNAL OF TRADITIONAL COMPLEMENTARY AND ALTERNATIVE MEDICINES., 9(3): 366-373.

[25] Rahmatullah, M., M.A. Haque Mollik, M. Nasir Ahmed, M.Z. Ahmed Bhuiyan, M. Maruf Hossain, M.N. Kabidul Azam, S.H. Seraj, M. Chowdhury, F. Jamal, S. Ahsan, R. Jahan, 2010. A Survey of Medicinal Plants used by Folk Medicinal Practitioners in Two Villages of Tangail District, Bangladesh. AMERICANEURASIAN JOURNAL OF SUSTAINABLE AGRICULTURE., pp: 357-363.

[26] Rahmatullah, M., A. Kumar Das, M.A. Haque Mollik, R. Jahan, M. Khan, T. Rahman and H.M. Chowdhury, 2009. An Ethnomedicinal Survey of Dhamrai Sub-district in Dhaka District, Bangladesh. AMERICAN-EURASIAN JOURNAL OF SUSTAINABLE AGRICULTURE., 3(4): 881-888.

[27] Razzaque, M.A. and M.G. Hossain, 2007. The Second Report on Plant Genetic Resources for Food and Agriculture of Bangladesh - The State of Activities. Bangladesh Agricultural Research Council Ministry of Agriculture.

[28] Ronzu Ahmmed, M., S. Ahmed, S.M.S. Islam Sunny, A. Kar, S.M. Neaz Mahmud, M. Humayun Kabir, S. Mahmud, S. Mahmud Shaon, 2017. A Study on Diversity of Medicinal Plant Usage by Folk Medicinal Practitioners in Different Villages of Dhunat Upazila, Bogra District, Bangladesh. JOURNAL OF PHARMACOGNOSY AND PHYTOCHEMISTRY., 6(1): 177- 186.

[29] Roy, S., M. Zashim Uddin, M. Abul Hassan, M. Matiur Rahman, 2008. Medico-botanical Report on the Chakma Community of Bangladesh. BANGLADESH JOURNAL OF PLANT TAXONOMY., 15(1): 6772.

[30] Tasannun, I., F. Akter Ruba, B. Uddin Bhuiyan, K. Mahbub Hossain, J. Khondokar, I. Malek, A.B.M. Anwarul Bashar, M. Rahmatullah, 2015. Indigenous Medicinal Practices: Medicinal Plants of Chakma Tribal Medicinal Practitioners in Rangamati District. AMERICAN-EURASIAN JOURNAL OF SUSTAINABLE AGRICULTURE., 9(5): 28- 35.

[31] Tous Zohora, F., S. M. Neaz Mahmud, A. Kar, S. Mahmud, A. Zaffar Shibly, 2016. A Survey on Medicinal Plant Usage by Folk Medicinal Practitioners in Different Villages of Haluaghat Upazila, Mymensingh District, Bangladesh. INDIAN JOURNAL OF RESEARCH IN PHARMACY AND BIOTECHNOLOGY., pp. 200.

[32] Tugume, P.K., E. Kakudidi, M. Buyinza, J. Namaalwa, M. Kamatenesi, P. Mucunguzi, J. Kalema, 2016. Ethnobotanical Survey of Medicinal Plant Species used by Communities around Mabira Central Forest Reserve, Uganda. JOURNAL OF ETHNOBIOLOGY AND ETHNOMEDICINE., 12(1): 5.

[33] Yusuf, M., M. Abdul Wahab., J. Uddin Chowdhury, J. Begum, 2006. Ethno-medico-botanical Knowledge from Kaukhali Proper and Betbunia of Rangamati District. BANGLADESH JOURNAL OF PLANT TAXONOMY., 13(1): 55-61. 
[34]Zashim Uddin, M., M. Abul Hassan, M. Rahman, K. Arefin, 2012. Ethno-medico-botanical Study in Lawachara National park, Bangladesh. BANGLADESH JOURNAL OF BOTANY., 41(1): 97-104.

[35]Zent, S., 2013. Processual Perspectives on Traditional Environmental Knowledge. In n: Roy Ellen, Stephen J. Lycett and Sarah E. Johns, eds. 2013. Understanding Cultural Transmission in Anthropology: A Critical Synthesis. NEW YORK OXFORD : BERGHAHN BOOKS., pp: 213-65. 